\title{
A Biblical Model for a Christian Hospital in India in the time of COVID-19
}

Vijay Anand Ismavela

${ }^{a}$ MS, MCh, Former Director, Makunda Christian Leprosy and General Hospital, Bazaricherra, Assam, India

Today is Palm Sunday, the beginning of the Christian "Passion Week." Normally, today, Christians all over the world would have walked streets outside their churches with palm fronds, enacting Jesus's entrance into Jerusalem, leading on to the train of events that led to His death and resurrection. Palm Sunday 2020, however, is different. Churches all over the world are closed. Most villages, towns, and cities are under various restrictions - from social distancing to lockdowns. People are on their phones talking, chatting, and posting on social media. The discussions are all about one thing - the COVID-19 pandemic. As of today, over 1.2 million people are infected and over 65,000 have died. $^{2}$

The Jewish world is about to start their Passover festival; this year it will also be celebrated across the world in similar conditions as Passion Week, from the $8^{\text {th }}$ to the $16^{\text {th }}$ of this month. We read the story of the Passover in Exodus 12:12-18. The nation of Israel was in bondage to the Egyptians. The ruler of the Egyptians, the Pharaoh, would not let them free; they were his source of cheap labor. The early chapters of Exodus talk about this situation, the story of Moses and God using him to deliver the Israelites from the clutches of the Egyptians through 10 plagues. The last plague was the death of every firstborn in the land. The Israelites were pre-warned of the impending plague and were told to anoint their doorposts with blood from a sacrificial lamb. When the Angel of Death swept through the land killing the firstborn, he "passed over" the homes where there was blood on the doorposts. We too, like the Israelites, should put our faith in the shed blood of the Lamb. The world today is gripped by a powerful pestilence, killing large numbers of people from even the wealthiest and most powerful of nations; all their power and wisdom is unable to stop it. We too have no power over this pestilence, but like the Israelites, we can put our faith in our God, who made heaven and earth. He sends His angels to watch over His people and like the Israelites in the days of Moses, we too can be at peace and without fear.

Our mission hospital in Assam, India has started to approach this crisis situation with a Biblical model. It comes from the first six chapters of the book of Nehemiah.

Nehemiah started his story from the city of Susa, where he heard about the sad predicament of the people of Judah and the city of Jerusalem. It is like our situation today, as we hear about the worsening crisis across the world. He knew that this situation was due to the unfaithfulness of God's people (Neh 1:8), but at that point in time, the priority was to restore the integrity of the city and its walls (Neh 2:5). He approached the king and was given supplies and assistance to complete this task. He was given authority, in fact, he was made the governor. He inspected the city and its walls and took stock of the situation (Neh 2:12-16). We too should understand and take stock of the situation. Through electronic mass media, we can be up to date on what is happening around the world. We know that this pandemic originated in China and then rapidly spread across the world through traveling 
infected people. It is now spreading from person to person. Each infected person is expected to spread the disease to two others, if given the opportunity to interact with uninfected people. If nothing is done, millions will be infected, and many will die. Scientists are constantly studying this disease as it evolves, and we are learning how to manage the situation and minimize morbidity and mortality.

Having understood what he was up against, Nehemiah made elaborate plans. He appointed key leaders to take responsibilities for rebuilding different parts of the walls of Jerusalem. When faced with ridicule by his enemies, he responded by ignoring them, showing single-minded determination to complete the task given to him and by prayer. When there was a threat of physical violence, he arranged for workers to continue working with construction materials in one hand and a weapon in the other (Neh 4:1516). We too have the responsibility of treating our patients while protecting ourselves and others from getting infected. At our hospital, the local government has designated us as a non-COVID emergency hospital. People need a safe place to go for their deliveries, strokes, and heart attacks, bowel perforations, and obstructed hernias. In the future, we may be called upon to work with COVID patients, too, if government facilities are overwhelmed. Our hospital has created a task force that has readied the hospital to tackle this situation. Separate teams have been formed, personal protective equipment (PPE) is being made with what we have, different areas have been designated for different patients, and protocols are in place. We, too, are preparing to fight on two fronts.

In the $5^{\text {th }}$ chapter of the book of Nehemiah, we see him hearing about the plight of the poor and needy. Although his task was to repair the walls, that could not be his only priority. His target population was suffering, and they were the

April 2020. Christian Journal for Global Health, 7(1) focus of the exercise, not the stone walls and wooden gates. Therefore, he steps in and asks people to forgive the debts of the poor and give loans without interest. In this moment of crisis, let us also consider the people we have been called to serve. Many of them were already poor and marginalized, this situation will make them destitute. They have just become financially vulnerable and in danger of losing their vital assets. If we force the poor to pay their bills for bringing their loved ones to our hospitals and their children to our schools, we would inflict greater pain than the virus. Let us think about how we can be a blessing to the underprivileged communities we have been called upon to serve. We may ask, aren't we running out of money too? We don't have enough to pay our bills and salaries. We must remember that God is no man's debtor. The Bible tells us that when we treat the poor, He will pay their bills and reward us (Proverbs 19:17).

Later in the $5^{\text {th }}$ chapter, we see Nehemiah counting the costs of the work entrusted to him. He finds that resources are short and the task is great. He decides to set a personal example by not claiming what is his due as a governor. When crisis situations arise, we (and our families and friends) should consider a period of austerity and sacrifice for the people we are called to serve. Makunda went through periods of severe crisis in the past. Each time, bills accumulated, due amounts were demanded by various people, salaries were deferred, and many staff donated from what they had to keep the work going. Projects had been started which could not be closed, and staff contributed to enable them to continue. Today, they are institutions on their own: the 1200 student Makunda Christian Higher Secondary School, the School of Nursing, and the branch hospital at Ambassa in Tripura. To enable these to become reality, staff were willing to wait for 14 years for running water and electricity to 
be supplied to their homes. Some staff did not take their eligible leave so that the hospital did not have to pay for replacements. Today, we too have an opportunity to help our institution continue to serve its target people by giving of our time, talents, and treasure. We are lending to God and will be repaid with things that money cannot buy, peace and contentment in this world and riches in heaven.

We read in Chapter six that Nehemiah firmly denied lies from his enemies and finally completed the task in 52 days. Only then did he start working on solving the root causes of the problem, the disobedience of God's people. We too need to work hard and diligently to get through this crisis now. When the threat has passed, we can study the entire experience and put in place protocols and practices to help us do better the next time we face another crisis.

We hear about fear in people facing this crisis, but we have nothing to fear. In Romans 14:8, Paul writes that whether we live or die, we are the Lord's. For Christians, life does not end with our physical death but continues on forever. We are God's ambassadors from the kingdom of Heaven, temporarily posted to this world. We will all die one day, but we are at peace. We have handed over our lives into the hands of our loving Commanding Officer. We are dispensable, and He can choose the manner and timing of our deaths. Our only concern is that during the time given to us in this world, we live lives that find approval in His sight by trust and obedience and to complete the tasks given to us.

\section{Conclusion}

The $23^{\text {rd }}$ Psalm is a much-loved chapter in the Bible. In verse 4 we read, "Even though I walk through the valley of the shadow of death, I fear no evil, for thy rod and thy staff, they comfort me." I remember suffering an acute myocardial infarction, rolling about in pain on 2008 October $12 .^{3}$ I felt as if someone was trying to pull the life out of me, but I was held on because God told me that He had some more work for me to do before I go to be with Him. In verse 6, we read, "Surely goodness and mercy will follow me all the days of my life and I will live in the house of the Lord forever." May we submit our lives to Him as we face this crisis and be found worthy of this promise, for this world and the one to come.

\section{References:}

1. Makunda Christian Leprosy \& General Hospital, Assam, India. http://www.makunda.in/

2. Channel News Asia. COVID-19 Map. Accessed 4 April 2020. Available from:

https://infographics.channelnewsasia.com/covid19/map.html

3. Ismavel VA. An encounter with myocardial infarction. The Sparrow's Nest. Blog. 1 Nov 2011. Available from: https://thesparrowsnest.net/2011/11/01/an-encounter-witha-myocardial-infarction/

Competing Interests: None declared.

Correspondence: Dr. Vijay Ismavel, Assam, India. ivijayanand@yahoo.in

Cite this article as: Ismavel VA. A biblical model for a Christian hospital in India in the time of COVID-19.

Christian Journal for Global Health. April 2020;7(1):27-29. https://doi.org/10.15566/cjgh.v7i1.371

(C) Author This is an open-access article distributed under the terms of the Creative Commons Attribution License, which permits unrestricted use, distribution, and reproduction in any medium, provided the original author and source are properly cited. To view a copy of the license, visit http://creativecommons.org/licenses/by/4.0/ 